\title{
Variety and phosphate fertilizer dose effect on nutrient composition, in vitro digestibility and feeding value of cowpea haulm
}

Terry Ansah*, Henry Ayindoh Algma and Herbert Kwabla Dei*

\begin{abstract}
Background: Cowpea (Vigna unguiculata [L.]) is a legume cultivated throughout most tropical countries and is valued as food and feed for human and livestock respectively. The search for an improved cowpea variety has been on-going with the aim of improving traits such as grain yield, drought and pest resistance. But no information exist on the feeding value of these improved varieties. Phosphate (P) fertilizer application is recommended to augment grain yield in grain legumes but data on the effect of $P$ fertilizer on haulm quality is limited.

Results: Two separate experiments were conducted to determine the effect of $P$ fertilizer dose on the nutritive value of haulms from different cowpea varieties $(V)$. In experiment 1, effect of three P doses $\left(30,60\right.$ and $90 \mathrm{~kg} \mathrm{P}_{2} \mathrm{O}_{5}$ / ha) on in vitro gas production (IVGP) characteristics, concentrations of digestible organic matter (DOM), crude protein (CP), acid detergent fiber (ADF) and neutral detergent fiber (NDF) of haulms from five cowpea varieties (Zaayura-SARC 4-75, Songotra-IT97K-499-35, Hewale-IT93K-192-4, IT99K 573-1-1 and Asomdwe-IT94K-410-2) were investigated using the $3(\mathrm{P}) \times 5(\mathrm{~V})$ factorial treatment arrangements in a completely randomized design. In experiment 2, the effects of two P doses (30 and $90 \mathrm{~kg} \mathrm{P}_{2} \mathrm{O}_{5} / \mathrm{ha}$ ) and two varieties (Zaayura-SARC 4-75 and Hewale-IT93K-192-4) on the voluntary feed intake, live weight, haematology and carcass characteristics of Djallonke lambs were also assessed using a $2(P) \times 2(V)$ factorial treatment arrangement. The $V \times P$ interaction significantly affected $C P, N D F$ and ADF with CP concentration increasing with increase in P doses in Zaayura-SARC 4-75 and Asomdwe-IT94K-410-2. Whilst an increase $(P<0.05)$ in NDF was observed in Songotra-IT97K-499-35and Asomdwe-IT94K-410-2 as $P$ doses increased, the other $V$ only increased from $P$ dose 30 to $60 \mathrm{~kg} / \mathrm{ha}$ and declined at $P$ dose $90 \mathrm{~kg} / \mathrm{ha}$. The ADF decreased $(P<0.05)$ with increase in $P$ dose for all $V$ with the exception of Songotra-IT97K-499-35. There was a significant $V$ effect on DOM with the highest reported in Zaayura-SARC 4-75 (43.44 \%). Daily DM intake, carcass length and blood urea nitrogen of the lambs were significantly affected by the $\mathrm{V} \times \mathrm{P}$ interaction. There was a significant $\mathrm{V}$ effect on globulin and $\mathrm{P}$ effect on live weight at slaughter, dressed weight, chuck, leg, loin, rib and flank and liver and lungs.

Conclusion: It can be concluded that nutrient concentrations of cowpea haulms were positively influenced by different $\mathrm{P}$ dose and varieties with favorable effects on growth, haematology and carcass composition of lambs. Varieties Zaayura-SARC 4-75 and Hewale-IT93K-192-4 at P dose at $90 \mathrm{~kg} / \mathrm{ha}$ are recommended to enhance growth performance and carcass yield of Djallonke lambs.
\end{abstract}

Keywords: Voluntary intake, Cowpea haulm, In vitro gas production, Djallonke, Phosphate fertilizer

\footnotetext{
* Correspondence: ansahterry@yahoo.com; tansah@uds.edu.gh;

University for Development studies, Faculty of Agriculture, Department of

Animal Science, Tamale, Ghana
} 


\section{Background}

Cowpea (Vigna unguiculata [L.]) is a legume cultivated throughout most tropical countries and is valued as food and feed for human and livestock respectively. It is drought tolerant, can be grown on relatively poor soils, and fixes nitrogen, thereby improving soil fertility [1]. Mixed farming is a common farming system in most tropical countries. Livestock in mixed farming systems are usually fed with residue from crop fields to sustain growth during periods of feed shortage.

Leguminous haulm like cowpea haulms are a major source of dietary protein supplement to ruminants fed basal diets from cereal residues or grazing natural pastures during the dry season in smallholder livestock systems [2]. Calves fed a basal diet of teff straw and supplemented with cowpea haulm were found to have an increased supply of microbial nitrogen [3]. In another study, where ewes were fed maize stover supplemented with cowpea haulm, DM intake, nutrient digestibility and rumen ammonia concentration were found to have improved [4].

Several dual purpose cowpea varieties have been bred with the aim of improving grain yield, pest resistance, and drought tolerance [5]. Investigating the nutritive value of the haulms from these new varieties is justified considering the important role they play in the livestock industry.

Application of phosphate $(\mathrm{P})$ fertilizer has been shown to increase grain yields in cowpea [6] but limited information exists on its effect on the feed value of haulms from different varieties in the tropics. Phosphate fertilization was found to affect crude protein, neutral detergent fiber and acid detergent fiber of sainfoin (Onobrychis sativa [L]) [7].

The in vitro gas production technique has over the years been proven to be the most reliable, simple and efficient way of evaluating feedstuff for their potential in the animal industry [8-10]. Rumen fluid for in vitro gas studies is often obtained from fistulated animals. However, in most African research institutions, these animals are normally not available mainly due to the cost of management and welfare. Some researchers have successfully used rumen fluid from slaughtered animals as substitute for the fistulated ones [11, 12]. The results were highly correlated with Tilley and Terry In vitro organic matter digestibility (IVOMD) $\left(R^{2}=0.73\right)$ and $\mathrm{ME}\left(R^{2}=0.92\right)$.

The objectives of this study were therefore to:

1) Determine the effect of three $P$ doses on the CP, NDF, ADF and gas production characteristics of haulms of five varieties.

2) Determine the effect of two P doses on dry matter intake, daily weight gain, carcass characteristics and blood biochemistry of Djallonke rams supplemented with haulms of two cowpea varieties.

\section{Methods}

\section{Study area}

The cowpea varieties were cultivated in Tingoli and Tibali in the Tolon and Savelugu Districts respectively, and are located in the Northern Region of Ghana. According to the Meteorological Services Departmenyt of Ghana, the Tolon District is characterised by a unimodal rainfall pattern with an average plant growth period of 183 days. The average rainfall per annum is $1057 \mathrm{~mm}$. The Savelugu District has an average rainfall of $1067 \mathrm{~mm}$ with an average plant growing period of 181 days.

The varieties (Zaayura-SARC 4-75, Songotra-IT97K-49935, Hewale-IT93K-192-4, IT99K 573-1-1 and AsomdweIT94K-410-2) were cultivated on an area of $1200 \mathrm{~m}^{2}$ with each variety occupying a total area of $300 \mathrm{~m}^{2}$. The intra and inter row spacing was $75 \mathrm{~cm} \times 20 \mathrm{~cm}$. The phosphate fertilizer $\left(\mathrm{P}_{2} \mathrm{O}_{5}\right)$ was applied 14 days after planting. They were harvested at flowering stage and air dried for 3 days after which they were packed and stored under shade for the trial.

The chemical analysis, in vitro gas production study and lamb growth trial were conducted at the Faculty of Agriculture, University for Development Studies (UDS), Nyankpala Campus, Tamale.

\section{Experiment 1}

The $5^{*} 3$ factorial in completely randomized design was used for the nutrient composition study. The factors were the five varieties of cowpea (Zaayura-SARC 4-75, SongotraIT97K-499-35, Hewale-IT93K-192-4, IT99K 573-1-1 and Asomdwe-IT94K-410-2) and the three phosphate fertilizer doses $(30 \mathrm{~kg} / \mathrm{ha}, 60 \mathrm{~kg} / \mathrm{ha}$ and $90 \mathrm{~kg} / \mathrm{ha})$ and were replicated 4 times.

Air dried samples of the haulm were taken and milled through $1 \mathrm{~mm}$ sieve screen and oven dried over night at $60{ }^{\circ} \mathrm{C}$ for the chemical analysis.

Total Nitrogen $(\mathrm{N})$ was determined using the micro Kjeldahl after which the $\mathrm{CP}$ was calculated by multiplying the $\mathrm{N}$ content by 6.25 [13]. The NDF was determined exclusive of residual ash with sodium sulfite and $\alpha$ - amylase whilst ADF was determined exclusive of residual ash. The procedure of Van Soest et al. [14] was followed and was run on the Ankom ${ }^{200}$ fiber analyzer.

The $5^{*} 3$ factorial in randomized complete block was used for the in vitro gas production experiment with each treatment replicated 2 times in each period. The factors were the five cowpea varieties and the three phosphate fertilizer doses. There were 4 periods in all and each period lasted for $48 \mathrm{~h}$. Period was used as block.

Approximately $200 \mathrm{mg}$ of the milled and oven dried samples were weighed into $50 \mathrm{ml}$ test tube for incubation. Buffer was prepared following the procedure of McDougall [15] and placed in a water bath with continuous supply of carbon dioxide $\left(\mathrm{CO}_{2}\right)$ until the rumen 
fluid was ready. Rumen fluid was collected from the rumen of 3 separate cattle after slaughter into prewarmed vacuum at the Tamale abattoir. The rumen fluid was strained through a four layer cheese cloth and mixed with the buffer in a ratio of 1:4 with continuous supply of $\mathrm{CO}_{2}$ to get the buffered rumen fluid. Approximately $30 \mathrm{ml}$ of the buffered rumen fluid was dispensed into each test tube containing the samples using a $50 \mathrm{ml}$ syringe and placed in water bath at $39^{\circ} \mathrm{C}$.

The gas production was measured using a digital manometer at 3, 6, 12, 24 and $48 \mathrm{~h}$. The contents of the test tubes were agitated each time the gas was measured.

The gas measured was fitted to the exponential model of Ørskov and McDonald [16] $\left(\mathrm{Y}=\mathrm{b}\left(1-\mathrm{e}^{\mathrm{ct}}\right)\right.$ to derive the degradation characteristics ( $\mathrm{b}$ and $\mathrm{c}$ ) where,

$$
\begin{aligned}
& \mathrm{Y}=\text { gas volume at time } \mathrm{t}(\mathrm{ml}) \\
& \mathrm{b}=\text { asymptotic gas production }(\mathrm{ml}) \\
& \mathrm{t}=\text { time }(\mathrm{h}) \\
& \mathrm{C}=\text { fractional rate of gas production }(\mathrm{ml} / \mathrm{h})
\end{aligned}
$$

Digestible organic matter (DOM) was calculated using the equation of Menke and Steingass [9]. DOM (\%)= $16.49+0.9042 \mathrm{GP}+0.0492 \mathrm{CP}+0.0387 \mathrm{ash}$

Where,

$\mathrm{GP}=$ gas production $(\mathrm{ml} / 200 \mathrm{mg} \mathrm{DM}$ at $24 \mathrm{~h})$

$\mathrm{CP}=$ crude protein $(\mathrm{g} / \mathrm{kg} \mathrm{DM})$

\section{Experiment 2}

\section{Lamb growth study}

Two of the cowpea varieties (Zaayura-SARC 4-75 and Hewale-IT93K-192-4) and two phosphate doses (30 kg/ha and $90 \mathrm{~kg} / \mathrm{ha}$ ) were selected for the lamb growth trial. These were selected based on their slightly superior in vitro digestibility.

The $2 * 2$ factorial in a completely randomized design was used for the lamb growth study. The factors were the two varieties of cowpea (Zaayura-SARC 4-75 and Hewale-IT93K-192-4) and two phosphate fertilizer doses (30 kg/ha and $90 \mathrm{~kg} / \mathrm{ha}$ ). There were 5 replicates (lambs) per treatments.

A total of 20 intact male Djallonke lambs (8-12 months old) with an initial average live body weight of $15.8 \pm 2.3 \mathrm{~kg}$ were purchased from different livestock markets in the Northern Region. The animals were housed individually in wooden cages with concrete floors. The cages were fitted with wooden feeding troughs and plastic watering bowls. The animals were fed with the haulms ad libitum at 07:00 $\mathrm{h}$ and released for grazing on natural pastures at 10:00 h. Water was also given ad libitum and was replaced at the same time of feeding. The animals were allowed 2 weeks period of adjustment to feed and cage.

\section{Supplementary feed intake}

Each week, $1 \mathrm{~kg}$ of each treatment was weighed into jute sacks from which the animals were fed daily. Samples of the haulms in the sack were taken daily and stored in a freezer until the experiment was over. After the experiment, the sampled feed was bulked for each treatment and subsamples taken for oven drying at $60^{\circ} \mathrm{C}$ for $48 \mathrm{~h}$.

The daily feed refusals in the trough were collected and weighed. After the entire experiment, the total feed refusal was subtracted from the total feed offered and expressed on DM basis to get the supplementary feed intake.

\section{Weekly live weight}

The weekly live weight of the animals were measured using a hanging scale (Camry hanging scale, ISO9001:2008, China). From the weekly live weight, the daily live weight gain was estimated by subtracting the initial weight from the final weight for each animal and dividing by the total number of days (56 days).

\section{Blood collection and processing}

Blood samples were taken at the end of the experiment for the haematology and blood metabolites. The blood samples were taken at about 07:00 h. Approximately $10 \mathrm{ml}$ of blood was taken with a syringe from the jugular vein and transferred into two sets of test tubes, one without anti-coagulant for the blood metabolite and the other with anti-coagulant (Ethylene di amine tetra acetic acid (EDTA)/ fluoride) for the haematological parameters. The blood sample without anti-coagulant was centrifuged and the serum separated. The serum was then transferred into clean test tubes and stored at $4{ }^{\circ} \mathrm{C}$ for the albumin, total protein, glucose and blood urea nitrogen (BUN) analysis. Globulin was calculated from total protein and albumin. The blood sample with anticoagulant was used for the analysis of haemoglobin $(\mathrm{Hb})$, white blood cells (WBC) and parked cell volume (PCV).

\section{Carcass characteristics}

Three animals were selected from each treatment group for the carcass analysis at the Meat Unit of the University for Development Studies, Tamale. Feed was withheld from the animals $24 \mathrm{~h}$ before slaughter and their weights taken to represent the slaughter weight. All animals were slaughtered and cut into parts on the same day. Immediately after slaughter, the skin, head, feet and testes (external organs) were removed and weighed. The dressed weight, dressing percentage and carcass length were taken and together with the slaughter weight were referred to as carcass parameters. The carcasses were eviscerated and the internal organs were removed and separately weighed. The internal organs (non-carcass characteristics) measured included, empty digestive tracts, liver, kidney, lungs, heart and spleen. Hot Carcass weight was taken after all 
the internal and external organs have been removed. The carcass was then cut into neck, shoulder, rib and flank, back, chuck, leg and loin.

\section{Statistical analysis}

The data from the chemical composition, in vitro gas and lamb growth were analysed as a 2 way ANOVA in Genstat 12th edition. In the in vitro gas study, period was used as block whereas in the lamb growth study, initial weight was used as a covariate in the analysis of the live weight.

\section{Results}

\section{Experiment 1}

The effect of $\mathrm{V}, \mathrm{P}$ dose and their interactions on $\mathrm{CP}$, NDF and ADF are presented in Table 1 . The $\mathrm{V} x \mathrm{P}$ interaction affected $(P<0.05)$ the CP, NDF and ADF. The highest $(P<0.05) \mathrm{CP}$ was recorded in Zaayura-SARC 475 at a $P$ dose of $60 \mathrm{~kg} / \mathrm{ha}$ with the least recorded in IT99K 573-1-1 at a P dose of 60 and $90 \mathrm{~kg} / \mathrm{ha}$. The CP at a $P$ dose of $30 \mathrm{~kg} /$ ha was consistently higher $(P<0.05)$ than the $\mathrm{P}$ dose of $90 \mathrm{~kg} / \mathrm{ha}$ for all the $\mathrm{V}$. The highest NDF was obtained in Songotra-IT97K-499-35 at a P dose of $90 \mathrm{~kg} / \mathrm{ha}$ with the least reported in HewaleIT93K-192-4 at $90 \mathrm{~kg} / \mathrm{ha}$. The ADF was in the range of $282 \mathrm{~g} / \mathrm{kg}$ DM and $352 \mathrm{~g} / \mathrm{kg}$ DM for Zaayura-SARC 4-75 at 60 and Songotra-IT97K-499-35 at $90 \mathrm{~kg} / \mathrm{ha}$ respectively.

The $\mathrm{V} x \mathrm{P}$ interaction was not significant for digestible organic matter (DOM), in vitro gas production (IVGP) and rate of gas production (c). There was a significant $\mathrm{V}$ effect on mean DOM. The DOM ranged from $404.0 \mathrm{~g} / \mathrm{kg}$ $\mathrm{DM}$ to $443.0 \mathrm{~g} / \mathrm{kg}$ DM for varieties Asomdwe-IT94K-4102 and Zaayura-SARC 4-75 respectively. The potentially degradable dry matter (g/kg DM), rate of degradation (c) and in vitro gas production at $48 \mathrm{~h}$ did not differ by $\mathrm{V}$ or by $\mathrm{P}$ (Table 1$)$.

\section{Experiment 2}

The results of the effect of $\mathrm{V}, \mathrm{P}$ and interactions on the lamb growth parameters are shown in Table 2 . The $\mathrm{Vx}$ $\mathrm{P}$ interaction affected $(P<0.05)$ the daily dry matter intake (DMI). The highest DMI was reported in lambs that fed on Hewale-IT93K-192-4 at a P dose of $30 \mathrm{~kg} / \mathrm{ha}$ and Zaayura-SARC 4-75 at a P dose of $90 \mathrm{~kg} / \mathrm{ha}$. The other growth parameters were not affected by the treatment interaction or the main effect.

There was a $\mathrm{V} \times \mathrm{P}$ interaction on carcass length with the animals on $\mathrm{V}$ at $90 \mathrm{~kg} / \mathrm{ha}$ having the longest $(P<0.05)$ carcass length (Table 3$)$. There was a significant $P$ effect on the slaughter weight and dressed weight with the higher $P$ dose having a greater $(P<0.05)$ influence.

The V $\mathrm{x} P$ interaction was not significant on the primal cuts. However, there was a significant main effect of $P$ dose on primal cuts. The lambs that fed on $P$ dose of $90 \mathrm{~kg} / \mathrm{ha}$ had higher $(P<0.05)$ back, chuck, leg, loin, shoulder and rib and flank than those on the $P$ dose of $30 \mathrm{~kg} / \mathrm{ha}$.

There was a significant $\mathrm{P}$ dose effect on the liver and lungs among the internal organs with animals on the $90 \mathrm{~kg} /$ ha $\mathrm{P}$ dose having the highest $(P<0.05)$ (Table 4$)$.

The haematology and blood biochemistry were not affected by the $\mathrm{V} x \mathrm{P}$ rate interaction and main effects, except for the globulin and blood urea nitrogen (BUN). Animals supplemented with Hewale-IT93K-192-4 at a P dose of $90 \mathrm{~kg} / \mathrm{ha}$ had higher $(P<0.05)$ BUN compared with the other treatments (Table 5). Similarly, animals on Hewale-IT93K-192-4 had higher $(P<0.05)$ globulin concentration compared to the other varieties.

\section{Discussion}

The differences observed in the nutrient composition and in vitro organic matter digestibility of the $\mathrm{V}$ at different $\mathrm{P}$ doses suggests the varieties could be selected for different dose of phosphate application. The CP concentrations reported in this study compared favorably with those reported by Anele et al. [17] for other improved

Table 1 Cowpea variety and phosphate fertilizer dose ( $\mathrm{kg} \mathrm{P}_{2} \mathrm{O}_{5} / \mathrm{ha}$ ) effects on crude protein (CP), neutral detergent fibre (NDF), acid detergent fibre (ADF) concentrations $(\mathrm{g} / \mathrm{kg})$ and $/ n$ vitro gas production characteristics of haulms $(\mathrm{g} / \mathrm{kg})$

\begin{tabular}{|c|c|c|c|c|c|c|c|c|c|c|c|c|c|c|c|c|c|c|c|}
\hline \multirow[t]{2}{*}{ Item } & \multicolumn{3}{|l|}{$\mathrm{Za}$} & \multicolumn{3}{|l|}{ So } & \multicolumn{3}{|l|}{$\mathrm{He}$} & \multicolumn{3}{|l|}{ IT } & \multicolumn{3}{|l|}{ AS } & \multirow[t]{2}{*}{ SED } & \multicolumn{3}{|c|}{$P$-value } \\
\hline & 30 & 60 & 90 & 30 & 60 & 90 & 30 & 60 & 90 & 30 & 60 & 90 & 30 & 60 & 90 & & $\mathrm{~V}$ & $P$ rate & $V \times P$ rate \\
\hline $\mathrm{CP}$ & 153 & 166 & 149 & 138 & 129 & 133 & 146 & 140 & 143 & 145 & 126 & 126 & 145 & 150 & 145 & 6.3 & 0.001 & 0.119 & 0.044 \\
\hline NDF & 478 & 481 & 462 & 489 & 545 & 554 & 503 & 508 & 460 & 491 & 512 & 507 & 480 & 518 & 533 & 20.3 & 0.001 & 0.032 & 0.020 \\
\hline $\mathrm{ADF}$ & 293 & 282 & 290 & 320 & 348 & 352 & 350 & 341 & 302 & 317 & 306 & 303 & 308 & 310 & 322 & 15.4 & 0.001 & 0.031 & 0.038 \\
\hline DOM & 436 & 442 & 425 & 416 & 430 & 416 & 419 & 438 & 420 & 443 & 433 & 426 & 418 & 404 & 411 & 5.0 & 0.001 & 0.087 & 0.290 \\
\hline B & 192 & 174 & 191 & 188 & 193 & 172 & 188 & 195 & 193 & 191 & 194 & 189 & 184 & 173 & 177 & 6.0 & 0.217 & 0.405 & 0.310 \\
\hline C & 0.07 & 0.07 & 0.06 & 0.06 & 0.07 & 0.07 & 0.06 & 0.07 & 0.07 & 0.07 & 0.06 & 0.06 & 0.06 & 0.06 & 0.07 & 1.0 & 0.855 & 0.410 & 0.740 \\
\hline IVGP 48 h (ml/g DM) & 18.4 & 16.8 & 18.3 & 16.4 & 18.8 & 16.8 & 16.6 & 18.8 & 17.7 & 17.3 & 15.6 & 17.1 & 17.4 & 15.6 & 17.2 & 7.0 & 0.241 & 0.849 & 0.209 \\
\hline
\end{tabular}

CP Crude protein, NDF Neutral detergent fiber, ADF Acid detergent fiber, $V$ Variety, $P$ Phosphate fertilizer dose, Za Zaayura-SARC 4-75, So Songotra-IT97K-499-35, He Hewale-IT93K-192-4, IT IT99K 573-1-1, As Asomdwe-IT94K-410-2), DOM Digestible organic matter, $b$ Potential degradability, $c$ Rate of degradation, IVGP In vitro gas production, SED standard error of difference, $P$ probability 
Table 2 Effect of haulms of cowpea variety and phosphate fertilizer dose on growth and carcass characteristics of Djallonke lambs

\begin{tabular}{|c|c|c|c|c|c|c|c|c|}
\hline \multirow[b]{2}{*}{ Intake and weight gain } & \multicolumn{2}{|c|}{ Zaayura } & \multicolumn{2}{|c|}{ Hewale } & \multirow[t]{2}{*}{ SED } & \multicolumn{3}{|l|}{$P_{\text {-value }}$} \\
\hline & 30 & 90 & 30 & 90 & & $\bar{V}$ & $P$ rate & $\overline{V \times P \text { rate }}$ \\
\hline Daily DM intake (g/h/d) & 125.5 & 143.9 & 145.1 & 127.7 & 6.9 & 0.621 & 0.730 & 0.003 \\
\hline ADWG (g) & 35.5 & 45.1 & 44.6 & 49.7 & 7.6 & 0.185 & 0.213 & 0.694 \\
\hline Slaughter Weight (kg) & 14.2 & 19.8 & 16.1 & 18.5 & 1.3 & 0.758 & 0.003 & 0.131 \\
\hline Dressed Weight (kg) & 5.6 & 7.7 & 6.2 & 7.1 & 0.5 & 0.976 & 0.001 & 0.097 \\
\hline Dressing \% & 39.3 & 38.9 & 38.5 & 38.4 & 1.8 & 0.592 & 0.841 & 0.915 \\
\hline Carcass Length (m) & 0.4 & 0.6 & 0.5 & 0.5 & 0.0 & 0.132 & 0.003 & 0.039 \\
\hline
\end{tabular}

ADWG Average daily weight gain, $A D W$ Average daily weight, $D M I$ Dry matter intake, $B W$ Body weight, $V$ Variety, $P$ Phosphate fertilizer dose, $D W$ Dressed weight, LW Live weight, SED standard error of difference, $P$ probability, Zaayura Zaayura-SARC 4-75, Hewale Hewale-IT93K-192-4

dual purpose cowpea. Turk et al. [18] reported an increase in CP concentration in sainfoin with increasing $\mathrm{P}$ dose. In this study, the $\mathrm{CP}$ concentration of the $\mathrm{V}$ responded differently to increasing $\mathrm{P}$ dose. The differences might have been influenced by the difference in legume specie and variety used. Leguminous plants that undergo biological nitrogen fixation are sensitive to phosphate deficiency since it is a major source of energy for Rhizobium bacteria to convert atmospheric nitrogen to ammonium for plant use [19]. This has the potential to significantly affect the nitrogen concentration of the cowpea haulm. The differences in $\mathrm{CP}$ concentration could be due to differences in the ability of the various $\mathrm{V}$ to take up nitrogen from the soil, since $\mathrm{P}$ was not limiting in this study. The CP levels reported in this study were above the adequate levels of 110-130 g/ $/ \mathrm{kg}$ required for maintenance and growth of small ruminants [20] and could therefore be used as supplemental CP source to ruminants fed low quality cereal straw.

The NDF and ADF values reported in this study were lower than what was reported by Anele et al. [17] in some other improved varieties of cowpea haulms cultivated without $\mathrm{P}$ application. The differences may have been due to the effect of the P fertilizer dose applied. Decreasing levels of NDF and ADF have been reported

Table 3 Effect of haulms of cowpea variety and phosphate fertilizer dose on primal cuts

\begin{tabular}{|c|c|c|c|c|c|c|c|c|}
\hline \multirow{2}{*}{$\begin{array}{l}\text { Primal cuts } \\
(\mathrm{kg})\end{array}$} & \multicolumn{2}{|c|}{ Zaayura } & \multicolumn{2}{|c|}{ Hewale } & \multirow[t]{2}{*}{ SED } & \multicolumn{3}{|c|}{$P$-value } \\
\hline & 30 & 90 & 30 & 90 & & $\bar{V}$ & P rate & $V \times P$ rate \\
\hline Back & 0.3 & 0.4 & 0.4 & 0.4 & 0.1 & 0.612 & 0.208 & 0.111 \\
\hline Chuck & 0.4 & 0.5 & 0.4 & 0.6 & 0.1 & 0.439 & 0.003 & 0.753 \\
\hline eg & 0.8 & 1.2 & 0.9 & 1.1 & 0.1 & 0.955 & 0.003 & 0.051 \\
\hline Loin & 0.3 & 0.4 & 0.4 & 0.4 & م & 0.424 & 0.017 & 0.310 \\
\hline Neck & 0.5 & 0.7 & 0.5 & 0.5 & 0.1 & 0.147 & 0.112 & 0.097 \\
\hline Rib and Flank & 0.4 & 0.6 & 0.6 & 0.6 & 0.1 & 0.089 & 0.008 & 0.197 \\
\hline Shoulder & 0.5 & 0.7 & 0.6 & 0.7 & 0.1 & 0.617 & 0.004 & 0.157 \\
\hline
\end{tabular}

$V$ Variety, $P$ Phosphorus fertilizer, DW Dressed weight, LW Live weight, SED Standard Error of Difference, $P$ probability, Means with the same letters within rows are not significantly different $(P>0.05)$, Zaayura Zaayura-SARC 4-75, Hewale Hewale-IT93K-192-4 in sainfoin with increasing $\mathrm{P}$ dose by Turk et al. [18]. This trend did not reflect in this study as different varieties were found to respond differently to increasing $\mathrm{P}$ doses in relation to NDF and ADF. Stage of harvesting is noted to significantly affect the deposition of plant cell wall (NDF and ADF). The vegetative growth phase of plants is usually characterised by lower NDF and ADF fraction with higher $\mathrm{CP}$ concentration than the reproductive or flowering growth phase [21]. The differences in NDF and ADF in the present study is an indication that the deposition of structural carbohydrates in cowpea haulms can be influenced by $\mathrm{V}$ and $\mathrm{P}$ doses even though they were all harvested at the same growth stage.

The differences in DOM among varieties could be explained by the differences in $\mathrm{CP}, \mathrm{NDF}$ and $\mathrm{ADF}$. The high $\mathrm{CP}$ may have supplied the needed degradable protein for cellulolytic microbes to digest the available organic matter.

The variation in DMI among the $\mathrm{V}$ at the different $\mathrm{P}$ doses might be attributed to the differences in CP, NDF and ADF concentrations at the different $\mathrm{P}$ dose. Higher $\mathrm{ADF}$ has been found to reduce voluntary DMI [22].

The dressing percentage reported in this study for the lambs marginally differed from the average $42.3 \mathrm{~kg}$ reported for Djallonke sheep slaughtered at $20 \mathrm{~kg}$ live weight [23]. The results from this study suggests that, supplementing the diet of Djallonke lambs grazing natural pasture with the different cowpea haulms treated with different $\mathrm{P}$ doses has the potential to improve the dressing percentage. The primal cuts, internal organs and external organs were higher in lambs fed haulms fertilized with a $90 \mathrm{~kg} \mathrm{P}$ dose than the $30 \mathrm{~kg} \mathrm{P}$ dose. This is an indication that fermentable organic matter was well synchronized with the dietary protein degraded in the rumen and therefore supplied the required volatile fatty acids (VFA) for muscle synthesis. Even though lower CP was obtained in haulms fertilized with a P dose of $90 \mathrm{~kg} / \mathrm{ha}$ compared to $30 \mathrm{~kg} / \mathrm{ha}$, the BUN concentration in animals supplemented with $\mathrm{P}$ dose $30 \mathrm{~kg} / \mathrm{ha}$ was higher, suggesting some limitation on the ability of the rumen microbes to effectively degrade the $\mathrm{CP}$ in the $\mathrm{P}$ dose $30 \mathrm{~kg} / \mathrm{ha}$ compared to 
Table 4 Effect of haulms of cowpea variety and phosphate fertilizer dose on internal and external organs of Djallonke lambs

\begin{tabular}{|c|c|c|c|c|c|c|c|c|}
\hline \multirow[t]{2}{*}{ Internal organs (kg) } & \multicolumn{2}{|c|}{ Zaayura } & \multicolumn{2}{|c|}{ Hewale } & \multirow[t]{2}{*}{ SED } & \multicolumn{3}{|c|}{$P$-value } \\
\hline & 30 & 90 & 30 & 90 & & V & $P$ rate & $\mathrm{V} \times \mathrm{P}$ rate \\
\hline Liver & 0.3 & 0.4 & 0.3 & 0.4 & 0.1 & 0.924 & 0.029 & 0.403 \\
\hline Lungs & 0.2 & 0.3 & 0.3 & 0.3 & 0.03 & 0.048 & 0.048 & 0.134 \\
\hline Empty digestive tract & 0.6 & 0.7 & 0.7 & 0.7 & 0.1 & 0.252 & 0.130 & 0.395 \\
\hline Heart & 0.1 & 0.1 & 0.3 & 0.1 & 0.2 & 0.349 & 0.349 & 0.324 \\
\hline Spleen & 0.04 & 0.05 & 0.05 & 0.04 & 0.009 & 0.803 & 0.803 & 0.461 \\
\hline Kidney & 0.07 & 0.07 & 0.07 & 0.08 & 0.008 & 0.580 & 0.122 & 0.580 \\
\hline \multicolumn{9}{|l|}{ External organs (kg) } \\
\hline Testis & 0.3 & 0.3 & 0.3 & 0.4 & 0.05 & 0.523 & 0.416 & 0.782 \\
\hline Skin & 1.0 & 1.4 & 1.3 & 1.3 & 0.11 & 0.969 & 0.014 & 0.373 \\
\hline Head & 1.2 & 1.7 & 1.3 & 1.5 & 0.01 & 0.329 & 0.001 & 0.028 \\
\hline
\end{tabular}

$V$ Variety, $P$ Phosphorus fertilizer, SED Standard Error of Difference, $P$ probability, Means with the same letters are not significantly different $(P>0.05)$, Zaayura Zaayura-SARC 4-75, Hewale Hewale-IT93K-192-4

the $90 \mathrm{~kg} / \mathrm{ha}$. This could further explain the differences in the carcass parameters reported between $\mathrm{P}$ dose $30 \mathrm{~kg} / \mathrm{ha}$ and $90 \mathrm{~kg} / \mathrm{ha}$.

Blood is an important index of physiological, pathological and nutritional status in living organisms [24]. The haematological values fell within the ranges reported for West African Dwarf Sheep [25, 26]. The Hb and PCV reported in this study were slightly higher than what was reported by Anele et al. [17] who fed cowpea haulm to West African Dwarf sheep. The stable $\mathrm{Hb}$ values reported in this study is an indication of the protein quality of the haulms. A higher BUN $(P<0.05)$ was reported in this study for Hewale-IT93K-192-4 at higher $\mathrm{P}$ dose indicating a better protein degradation in the rumen of the lambs on a $\mathrm{P}$ dose of $90 \mathrm{~kg} / \mathrm{ha}$. Globulin concentration could give an indication of the immune response of an organism [27]. The globulin concentrations reported in this study were enough to support the immune system of the lambs. The slightly higher $(P<0.05)$ globulin in Hewale-IT93K-192-4, suggest a better microbial degradation of the CP in Hewale-IT93K-192-4 than
Zaayura-SARC 4-75 even though Zaayura-SARC 4-75 had a higher CP than Hewale-IT93K-192-4.

\section{Conclusion}

The study showed a strong Variety and phosphate fertilizer dose effects on the nutrient composition, digestible organic matter and growth performance of Djallonke sheep. When selecting and cultivating dual purpose cowpea, the dose of phosphate fertilizer application should be taken into consideration. All the varieties at the various $\mathrm{P}$ doses have potential to be used as supplementary feed for Djallonke rams grazing natural pasture. Varieties Zaayura-SARC 4-75 and Hewale-IT93K-192-4 at a P dose of $90 \mathrm{~kg} / \mathrm{ha}$ are recommended for WAD sheep supplementation to enhance slaughter and dressed weights.

\section{Statement of ethics approval}

The component of the study that had to do with the use of animals were conducted in accordance with the ethics policy (2010) of the Institute of Continuing Education

Table 5 Effect of haulms of cowpea variety and phosphate fertilizer dose on the blood profile of Djallonke lambs

\begin{tabular}{|c|c|c|c|c|c|c|c|c|}
\hline \multirow[b]{2}{*}{ Blood profile } & \multicolumn{2}{|c|}{ Zaayura } & \multicolumn{2}{|c|}{ Hewale } & \multirow[t]{2}{*}{ SED } & \multicolumn{3}{|l|}{$P_{\text {-value }}$} \\
\hline & 30 & 90 & 30 & 90 & & $\mathrm{~V}$ & $P$ rate & $V \times P$ rate \\
\hline $\mathrm{Hb} \mathrm{g} / \mathrm{l}$ & 10.3 & 10.2 & 10.3 & 9.9 & 0.9 & 0.731 & 0.612 & 0.827 \\
\hline PCV \% & 31.0 & 30.6 & 30.8 & 29.5 & 2.6 & 0.720 & 0.624 & 0.826 \\
\hline WBC Total $\times 10^{9} \mathrm{~L}$ & 5.9 & 5.7 & 6.5 & 5.8 & 0.8 & 0.584 & 0.410 & 0.635 \\
\hline Albumin (g/l) & 26.2 & 24.9 & 24.3 & 24.0 & 1.0 & 0.079 & 0.331 & 0.504 \\
\hline Globulin (g/l) & 12.8 & 11.3 & 15.1 & 16.1 & 1.9 & 0.023 & 0.859 & 0.387 \\
\hline Glucose $(\mathrm{mmol} / \mathrm{l})$ & 0.6 & 0.5 & 0.8 & 0.64 & 0.2 & 0.113 & 0.283 & 0.871 \\
\hline Total Protein (g/l) & 38.9 & 36.2 & 39.4 & 40.2 & 1.9 & 0.124 & 0.469 & 0.209 \\
\hline Blood urea nitrogen $(\mathrm{mmol} / \mathrm{l})$ & 10.9 & 10.3 & 9.0 & 12.2 & 1.1 & 0.997 & 0.124 & 0.032 \\
\hline
\end{tabular}

Means with the same letters are not significantly different $(P>0.05), H b$ Haemoglobin, PCV Packed cell volume, WBC White blood cell, Zaayura Zaayura-SARC 4-75, Hewale Hewale-IT93K-192-4, V Variety, $P$ Phosphorus fertilizer, SED Standard Error of Difference, $P$ probability 


\section{and Interdisciplinary Research (ICEIR) of the University for Development studies, Tamale, Ghana.}

\section{Competing interest}

The authors declare that they have no competing interests.

\section{Authors' contributions}

TA supervised data collection and analysis and was fully in charge of paper writing. HAA collected and analysed the data and was part of the paper writing. HKD was actively involved in the paper writing and internal review. All authors have read and approve of the manuscript submission.

\section{Acknowledgement}

The authors are thankful to the Africa Research in Sustainable Intensification for the Next Generation (Africa RISING) project in Ghana of the International Institute of Tropical Agriculture (ITA) for providing the funds for this study. Special thanks to Dr. Asamoah Larbi for the editorial assistance.

\section{Received: 1 December 2015 Accepted: 20 April 2016}

\section{Published online: 01 June 2016}

\section{References}

1. Grings EE, Tarawali SA, Blummel M, Musa A, Fatokun C, Hearne S, et al. Proc. 5th World Cowpea Conference. Senegal: IITA; 2012. p. 323-33.

2. Tolera A, Yami A, Alemu D. Livestock feed resources in Ethiopia: challenges, opportunities and the need for transformation. Addis Ababa: Ethiopian Animal Feed Industry Association; 2012. p. 37-46.

3. Abule E, Umunna NN, Nsahlai IV, Osuji PO, Alemu Y. The effect of supplementing teff (Eragrostis tef) straw with graded levels of cowpea (Vigna unguiculata) and lablab (Lablab purpureus) hays on degradation, rumen particle passage and intake by crossbred (Friesian $\times$ Boran (zebu)) calves. Lives Product Sci. 1995:44:221-8.

4. Chakeredza S, ter Meulen U, Ndlovu LR. Ruminal fermentation kinetics in ewes offered a maize stover basal diet supplemented with cowpea hay, groundnut hay, cotton seed meal or maize meal. Trop Anim Prod. 2002;34:215-23.

5. Singh BB, Tarawali SA. Cowpea and its improvement: key to sustainable mixed crop/livestock farming systems in West Africa. In: Renard C, editor. Crop residues in sustainable mixed crop/livestock farming systems. Wallingford: CAB International; 1997. p. 79-100.

6. Singh A, Baoule AL, Ahmed HG, Dikko AU, Aliyu U, Sokoto MB, Alhassan J, Musa M, Haliru B. Influence of phosphorus on the performance of cowpea (Vigna unguiculata (L.) Walp.) Varieties in the sudan savanna of Nigeria. Agric Sci. 2011;2:313-7.

7. Turk M, Albayrak S, Yuksel O. Effects of phosphorus fertilization and harvesting stages on forage yield and quality of narbon vetch. The New Zealand J Agric Res. 2007;50:457-62.

8. Ørskov ER, Hovell FD, Mould F. The use of the nylon bag technique for the evaluation of feedstuffs. Trop Anim Prod. 1980;5:195-213.

9. Menke KH, Steingass H. Estimation of the energetic feed value obtained from chemical analysis and in vitro gas production using rumen fluid. Anim Res and develop. 1988;28:7-55.

10. Theodorou MK, Williams BA, Dhanoa MS, McAllan AB, France J. A simple gas production method using a pressure transducer to determine the fermentation kinetics of ruminant feeds. Anim Feed Sci Technol. 1994:48:185-97.

11. Chaudhry AS, Mohamed RAI. Fresh or frozen rumen contents from slaughtered cattle to estimate in vitro degradation of two contrasting feeds. Czech J Anim Sci. 2012;57:265-73.

12. Mutimura M, Myambi CB, Gahunga P, Mgheni DM, Laswai GH, Mtenga LA, Gahakwa D, Kimambo AE, Ebong C. Rumen liquor from slaughtered cattle as a source of inoculum for in-vitro gas production technique in forage evaluation. Agric J. 2013;8:173-80

13. AOAC. Official methods of analysis of AOAC international. 17th ed. 2000

14. Van Soest PJ, Robertson JB, Lewis BA. Methods for dietary fiber, neutral detergent fiber, and non-starch polysaccharides in relation to animal nutrition. J Dairy Sci. 1991;74:3583-97.

15. McDougall El. Studies on ruminant saliva; The composition and output of sheep's saliva. Biochem J. 1948:43:99-109.

16. Ørskov ER, McDonald I. The estimation of protein degradability in the rumen from incubation measurements weighted according to rate of passage. J Agric Sci (Cambridge). 1979;92:499-503.
17. Anele UY, Arigbede OM, Südekum KH, Ike KA, Olanite JA, Amole GA, Dele PA, Jolaosho AO. Effects of processed cowpea (Vigna unguiculata L. Walp) haulms as a feedsupplement on voluntary intake, utilization and blood profile of West Africa dwarf sheep fed abasal diet of Pennisetum purpreum in the dry season. Anim Feed Sci Technol. 2010;159:10-7.

18. Turk M, Albayrak S, Tuzun CG, Yuksel O. Effects of fertilization and Harvesting stages on forage Yield and Quality of sainfoin (Onobrychis sativa I.). Bulgarian J of Agric Sci. 2011;17:789-94.

19. Crowder LV, Chheda HR. Tropical grassland husbandry. Tropical agri. Series. London: Longman; 1982.

20. NRC (National Research Council). Nutrient requirements of small ruminants. sheep, goats, cervids and New World Camelids. National Academy of Science: Washington; 2007.

21. Ncube S, Saidi PT, Halimani TE. Effect of stage of growth and processing methods on the nutritional content of Acacia angustissima leaf meal harvested for broiler feeding. Livest. Res. for Rural Develop. 2015. p. 27.

22. Riaz MQ, Südekum KH, Clauss M, Jayanegara A. Voluntary feed intake and digestibility of four domestic ruminant species as influenced by dietary constituents: A meta-analysis. Livest Sci. 2014;162:76-85.

23. FAO (Food and Agriculture Organization). Small ruminant production and the small ruminant genetic resource in tropical Africa. Rome: Animal production and health paper; 1991.

24. Ewuola EO, Folayan OA, Gbore FA, Adebunmi Al, Akanji RA, Ogunlade JT, Adeneye JA. Physiological response of growing West African Dwarf goats fed groundnut shell-based diets as the concentrate supplements. Bowen J Agric. 2004;11:61-9.

25. Baiden RY, Rhule SWA, Otsyina HR, Sottie ET, Ameleke G. Performance of West African dwarf sheep and goats fed varying levels of cassava pulp as a replacement for cassava peels. Livest Res for Rural Develop. 2007;19.

26. Bawala TO, Adegoke EO, Ojekunle AO, Adu IF, Aina ABJ. Utilization of cassava peel and rumen epithelial waste diets by West African dwarf sheep. Asset Series A. 2007;7:168-80.

27. Ismail AM, Abou-El-Ellaa MA, Sedki AA. Blood metabolites, growth and reproductive performance and immune responsiveness in growing and doe rabbits as affected by Acitrol treatments. Egyptian J of Agric Res. 2002;80: 1789-808.

\section{Submit your next manuscript to BioMed Central and we will help you at every step:}

- We accept pre-submission inquiries

- Our selector tool helps you to find the most relevant journal

- We provide round the clock customer support

- Convenient online submission

- Thorough peer review

- Inclusion in PubMed and all major indexing services

- Maximum visibility for your research

Submit your manuscript at www.biomedcentral.com/submit
Biomed Central 